\title{
Environmental assessment tools for the evaluation and improvement of European livestock production systems
}

\author{
Niels Halberg ${ }^{\text {a,* }}$, Hayo M.G. van der Werf ${ }^{\mathrm{b}}$, Claudine Basset-Mens ${ }^{\mathrm{b}}$, \\ Randi Dalgaard ${ }^{\mathrm{a}}$, Imke J.M. de Boer ${ }^{\mathrm{c}}$ \\ ${ }^{a}$ Danish Institute of Agricultural Sciences, Denmark \\ ${ }^{\mathrm{b}}$ Institut National de la Recherche Agronomique, Rennes, France \\ ${ }^{\mathrm{c}}$ Animal Production Systems Group, Wageningen University and Research Center, The Netherlands
}

\begin{abstract}
Different types of assessment tools have been developed in Europe with the purpose of determining the environmental impact of various livestock production systems at farm level. The assessment tools differ in terms of which environmental objectives are included and how indicators are constructed and interpreted. The paper compares typical tools for environmental assessment of livestock production systems, and recommends selected indicators suitable for benchmarking. The assessment tools used very different types of indicators ranging from descriptions of farm management and quantification of input to estimates of emissions of, e.g., nitrate and ammonia. The indicators should be useful in a benchmarking process where farmers may improve their practices through learning from farms with better agri-environmental performance. An example of this is given using data on P-surplus on pig farms. Some indicators used the area of the farm as the basis of the indicator-e.g. nitrogen surplus per hectare - while others were expressed per unit produced, e.g. emission of greenhouse gasses per kilogram milk. The paper demonstrates that a comparison of organic vs. conventional milk production and comparison of three pig production systems give different results, depending on the basis of the indicators (i.e. per hectare or per kilogram product). Indicators linked to environmental objectives with a local or regional geographical target should be area-based - while indicators with a global focus should be product-based. It is argued that the choice of indicators should be linked with the definition of the system boundaries, in the sense that area-based indicators should include emissions on the farm only, whereas product-based indicators should preferably include emissions from production of farm inputs, as well as the inputs on the actual farm. The paper ends with recommendations for choice of agri-environmental indicators taking into account the geographical scale, system boundary and method of interpretation.
\end{abstract}

(C) 2005 Elsevier B.V. All rights reserved.

Keywords: Environmental assessment tools; Livestock production systems; Life Cycle Assessment, LCA; Indicators; Product oriented; Green accounts; Nutrient balance; Emissions; Greenhouse gasses; Organic farming

\footnotetext{
* Corresponding author. Tel.: +458999 1206 .

E-mail addresses: Niels.Halberg@agrsci.dk (N. Halberg), Imke.deBoer@wur.nl (I.J.M. de Boer).
} 


\section{Introduction}

As one of the responses to the strong focus on agri-environmental issues in Europe, different environmental assessment tools have been developed in order to determine the environmental impact of various livestock production systems. Some assessment tools are targeted for use at national or EU level for guiding policy (e.g. the set of agri-environmental indicators under the acronym "IRENA"; Indicator Reporting on the integration of Environmental concerns into Agricultural policy; EEA, 2004b, in press) or for diagnosis of agricultural systems. Other environmental assessment tools have been developed with the aim of improving farm management by supplying information to the farmer or advisor (Van der Werf and Petit, 2002; Goodlass et al., 2003). For each target group, effective environmental assessment tools are required in order to improve knowledge on environmental impact of current production systems and to find solutions to reduce the negative impacts. Assessment tools not only differ in target group, they also vary in their focus on environmental issues, and in the basic choice of indicator types (Halberg et al., 2005). It is therefore problematic that for several of these tools no explicit argumentation is given for target group, environmental issues and indicator types chosen.

Most indicators are process-oriented and use a land-based scaling of the agri-environmental topics (e.g. nutrient surplus per hectare, energy use per hectare) and include only on-farm emissions, meaning that emissions associated with the production of inputs (e.g. concentrated feed, fertiliser) are not considered. However, there is an increasing interest in product-oriented and life cycle based environmental assessments (LCA), because there is a need to evaluate global emissions and impacts from the whole production chain in relation to types and amounts of products consumed. The recent EU communication on Integrated Product Policy (IPP; Anonymous, 2003) states that

All products cause environmental degradation in some way, whether from their manufacturing, use or disposal. Integrated Product Policy (IPP) seeks to minimise these by looking at all phases of a products' lifecycle and taking action where it is most effective.
Product-oriented assessment is often based on LCA and expresses resource use and emissions per unit of product, e.g. greenhouse gas emission per kilogram pork. Several LCA studies on food have been published (De Boer, 2003; Halberg, 2004) and some indicator tools for agri-environmental assessment are (partly) based on LCA methodology.

The overall aim of this paper is to give a critical evaluation and guidelines for efficient use of agrienvironmental indicator types and tools. More specifically the paper will:

- Give a state-of-the-art overview of different environmental assessment tools for improved diagnosis, development, advice and management of livestock farming systems.

- Discuss how to improve the agri-environmental performance of livestock farming systems using benchmarking based on the variation in indicator values between comparable farms.

- Compare the land-based (input output accounting/ green accounts, etc.) and the product-oriented (LCA) approaches and indicators.

- Give recommendations for future development and harmonisation of agri-environmental evaluation tools for livestock farming for use in extension, diagnosis and research.

\section{Indicator tools for environmental assessment of livestock systems}

The relation between agricultural activities and their environmental impact is not simple and usually it is not possible to directly measure the environmental impact caused by a farm because most of the emissions are diffuse. Therefore, indicators are used to give information regarding the relation between a certain agricultural activity and its impact on resource use and environment. The idea of using indicators is thus based on the need to simplify complex phenomena and quantify information, so that its significance is more readily apparent. As stated by Stolze et al. (2000):

An indicator is a value derived from parameters, which points to the state of the environment with a significance extending beyond that directly associated with a parameter value. 
Table 1

Agri-environmental indicators used at national and EU level in the monitoring of environmental impacts of agriculture by the European Environment Agency ${ }^{1}$

\begin{tabular}{|c|c|c|c|c|}
\hline Driving force ${ }^{2}$ & Pressure & State & Impact & Response \\
\hline Fertiliser use per hectare & Nitrogen and & Nitrates in water & \multirow{4}{*}{$\begin{array}{l}\text { No. wild species } \\
\text { in fields }\end{array}$} & Area under organic farming \\
\hline Pesticide use per hectare & phosphorus surplus & Pesticide residues in water & & "\% farmers under Agri-Env. Schemes" \\
\hline Energy use per hectare & & & & \\
\hline $\begin{array}{l}\text { "\% farms specialised } \\
\text { in livestock" }\end{array}$ & $\begin{array}{l}\text { Nitrate and } \\
\text { ammonia emission }\end{array}$ & $\%$ soil organic matter & & $\begin{array}{l}\text { "\% of Natura } 2000 \text { sites in } \\
\text { agricultural land" }\end{array}$ \\
\hline
\end{tabular}

1. EEA, 2003; 2. EEA, 2004b, in press; See text for explanation of the different phases.

An indicator, therefore, is not simply any parameter one could imagine measuring, but one that should be selected according to specific needs for information related to certain objectives. The European Environmental Agency is presently developing a list of agrienvironmental indicators, "IRENA" (EEA, 2004b, in press), following the principles of the Driving-ForcePressure-State-Impact-Response (DPSIR) concept (Smeets et al., 1999). The DPSIR framework is used as a structure for the selection of environmental indicators based on whether an indicator describes an agro-economic Driving force (D, e.g. the causes), the environmental Pressure (P, e.g. emissions of pollutants), the State (S, or quality) of the environment/ recipient, the Impact (I) this has on the health of people, animals and ecosystems or a Response ( $\underline{R})$ to degraded environment in the form of policies and targets. The concept builds on the idea that indicator selection should be guided by the cause-effect relationships between the $\mathrm{D}$ and their related $\mathrm{P}$ on the one hand, and the changes in the S and the resulting I on the other hand. In this way the selection of proper D and $\mathrm{P}$ indicators should help to foresee and predict important negative changes in the environment in due time. As shown in Table 1, the fertiliser and pesticide use are D indicators while the EEA uses the nutrient surplus and estimates of greenhouse gas emissions as $P$ indicators.

The EEA has also defined some S and I indicators, such as the level of nitrate in water and the level of $\mathrm{C}$

Table 2

Characteristics of indicator-based environmental assessment tools for use in livestock production systems

\begin{tabular}{|c|c|c|c|c|c|c|c|}
\hline \multirow[t]{3}{*}{ Assessment tools } & \multicolumn{7}{|c|}{ Characteristics of the assessment tool } \\
\hline & \multirow[t]{2}{*}{ Start date } & \multirow[t]{2}{*}{$\begin{array}{l}\text { No. Farmers } \\
\text { using method }\end{array}$} & \multirow[t]{2}{*}{ Intended users } & \multirow{2}{*}{$\begin{array}{l}\text { Time/year } \\
\text { for data } \\
\text { collection }\end{array}$} & \multirow[t]{2}{*}{$\begin{array}{l}\text { Basis of } \\
\text { indicators }\end{array}$} & \multicolumn{2}{|c|}{$\begin{array}{l}\text { Scale of environmental } \\
\text { effects considered }\end{array}$} \\
\hline & & & & & & Local/regional $^{\mathrm{a}}$ & Global \\
\hline 1. ${ }^{\mathrm{b}} \mathrm{GA}$ Green accounts for farms & 1999 & 600 & $\begin{array}{l}\text { Farmers, farmer } \\
\text { advisors }\end{array}$ & $2-3 \mathrm{~h}$ & Inputs & + & 0 \\
\hline 2. EP Ecopoints & 1990 & 1500 & $\begin{array}{l}\text { Farmers, local } \\
\text { government }\end{array}$ & $1-2$ days & Farmer practices & + & 0 \\
\hline $\begin{array}{l}\text { 3. EMA Environmental } \\
\text { Management for Agriculture }\end{array}$ & 1997 & 5000 & $\begin{array}{l}\text { Farmer advisors, } \\
\text { farmers }\end{array}$ & $<1$ day & Farmer practices & + & $+/ 0$ \\
\hline 4. DIA DIALECTE & 1994 & 1000 & Farmer advisors & 1 day & $\begin{array}{l}\text { Inputs/farmer } \\
\text { practices }\end{array}$ & + & + \\
\hline $\begin{array}{l}\text { 5. LCAE LCA for Environmental } \\
\text { farm management }\end{array}$ & 1998 & 13 & $\begin{array}{l}\text { Farmer advisors, } \\
\text { researchers }\end{array}$ & $>2$ days & Effects & $+/ 0$ & + \\
\hline 6. EF Ecological Footprint & 1996 & $?$ & Researchers & $<1$ day & Effects & 0 & + \\
\hline
\end{tabular}

${ }^{a}$ Symbols indicate the extent to which an effect is taken into account, + : effect is considered, $+/ 0$ : effect is considered to a minor degree, 0 : effect is not considered.

b 1, Anonymous (2000); 2, Mayrhofer et al. (1996); 3, Lewis and Bardon (1998); 4, Solagro (2000); 5, Rossier (1999), 6, Wackernagel and Rees (1996). 
in soils, and as R indicators the percentage of organic farming and the number of farms participating in agrienvironmental schemes are considered. The full list of indicators may be found in EEA (2004b, in press). The IRENA indicators are to be used at a high hierarchical level (regions and countries) and the list cannot be used as a blueprint for selection of indicators for farm level management tools or green accounts. But this EEA framework may be used to compare the selection of indicators at farm level and to better understand the objectives of using specific indicators vis-à-vis the cause-effect relations in the DPSIR scheme.

A large variety exists - at both methodological and operational levels - within agri-environmental indicators used in farm level assessment tools for improved farm management and advice as reviewed recently by Van der Werf and Petit (2002) and Halberg et al. (2005). Most indicators are embedded in a diagnosis tool for either research or advisory purposes with procedures for calculation and presentation of the results for a specific farm over a period of time, usually a year. While a large number of such tools have been developed, only a small proportion address livestock farming systems and the important interactions between crop and livestock production (Goodlass et al., 2003). Tables 2 and 3 give an overview of six indicator systems selected to illustrate different approaches suitable for the assessment of livestock systems. Some of these farm level agri-environmental assessment tools use indicators based on quantification of inputs or emissions, e.g. nutrient surplus and potential losses and energy use per hectare. Other tools are based on recordings of the farmers' activities, farmer practices, e.g. whether the farmer uses soil covers or direct drilling methods. The tools also differ in the environmental aspects they address (Table 3); the GA and the LCA-based tool focus on Pressure indicators, while the other tools focus on Driving forces or changes in the State of e.g. landscape, biodiversity or soil on the farm. Only methods that were sufficiently different from each other, well-documented and showing proof of having been actually used or at least tested for assessment purposes were retained. For some of the types of assessment tools several specific tools have been developed independently in Europe and the one presented here is simply chosen as an example.
Table 3

Environmental aspects included in six environmental assessment tools for agriculture grouped as input related, emission related, and related to the state of the system

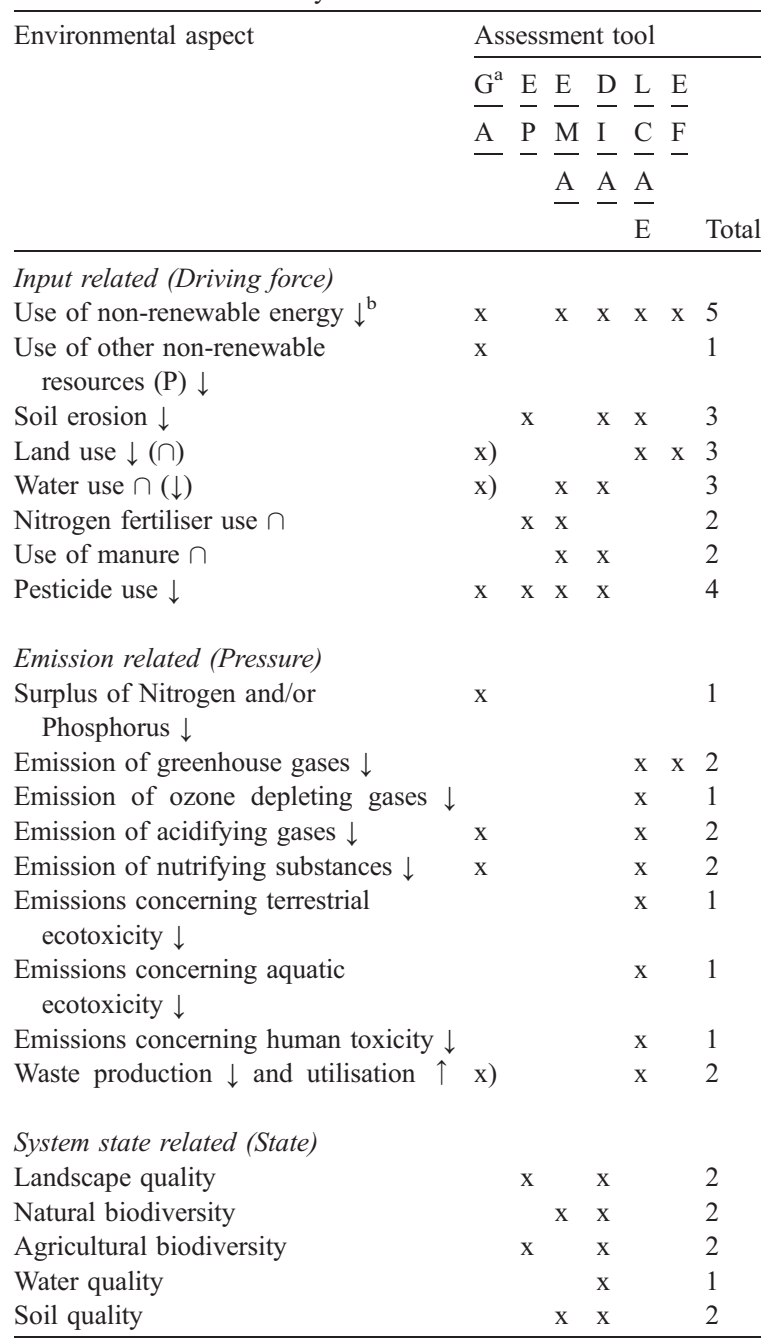

An $\mathrm{x}$ indicates that the objective is taken into account. The notion $\mathrm{x}$ ) indicates that the objective is only included if the farmer selects it. a See Table 1 .

b $\downarrow$, objective to be minimised; $\cap$, objective to be optimised; $\uparrow$, objective to be maximised.

\subsection{Green accounts for farms (GA)}

The Danish Green Accounts is a farmer tool to calculate and report nutrient balances and the use of energy and pesticides in the form of indicators based on the actual input and yields on the farm. Farmers are subsidized up to 1000 euro per year under the 
EU-supported agri-environmental schemes to carry out the Green Accounts, usually with the help of an advisor. The idea is that the Green Accounts would improve agri-environmental performance on a voluntary basis through a benchmarking process where farmers compare their own results against similar farms. The Danish advisory service reports average figures from Green Accounts on the Internet (Holbeck and Kolind Hvid, 2004). The farm gate nutrient balance calculations for nitrogen and phosphorus are based on $\mathrm{N}$ and $\mathrm{P}$ content in all farm inputs and in products exported from the farm. Surplus of $\mathrm{N}$ and $\mathrm{P}$ are reported per hectare (i.e. as $P$ indicators), but without any estimates of the different emissions. Energy use is limited to the use of diesel (reported as megajoule per hectare) and electricity at farm level (Table 4). Pesticide use is accounted for in the quantification of "amount of active ingredients used per ha" and "Treatment Frequency Index (TFI)" based on the sum of amounts used divided by standard approved dosages per hectare.

In the Netherlands, agricultural farms are obliged to report their nutrient inflow and outflow, using MINAS (MINeral Accounting System; Bureau Heffingen, 2001). The difference between nutrient input and output is called the farm surplus, and is assumed to be lost to the environment. These surpluses are regulated by comparing them to environmentally

Table 4

Description of indicators used in six environmental assessment tools for the evaluation of non-renewable energy use, soil erosion, nitrogen emissions and biodiversity on livestock farms

\begin{tabular}{|c|c|c|c|c|}
\hline \multirow[t]{2}{*}{ Method } & \multicolumn{4}{|l|}{ Objective } \\
\hline & $\begin{array}{l}\text { Use of non-renewable } \\
\text { energy }\end{array}$ & Soil erosion & Emissions of nitrogen & Natural biodiversity \\
\hline $1^{\mathrm{a}} \mathrm{GA}$ & $\begin{array}{l}\text { Input of direct }{ }^{\mathrm{b}} \text { non-renewable } \\
\text { energies }(\mathrm{GJ} / \mathrm{ha}) \text {. }\end{array}$ & & $\begin{array}{l}\text { Farm level } \mathrm{N} \text {-surplus, sum of } \\
\text { all imported } \mathrm{N} \text { minus all } \mathrm{N} \text { in } \\
\text { sold products, corrected for } \\
\text { changes in stocks }(\mathrm{kg} / \mathrm{ha}) \text {. }\end{array}$ & \\
\hline $2 \mathrm{EP}$ & & $\begin{array}{l}\text { Score based on soil cover by } \\
\text { crops, use of undersowing, } \\
\text { direct drilling and mulching, } \\
\text { presence of perennial crop. }\end{array}$ & & $\begin{array}{l}\text { Score based on age of } \\
\text { grassland: }<5 \text { years lowest, }>20 \\
\text { years highest. Score based on } \\
\text { presence of hedges, trees, } \\
\text { wetlands, orchards. }\end{array}$ \\
\hline 3 EMA & $\begin{array}{l}\text { Score based on: input of direct } \\
\text { non-renewable energies }+ \text { best } \\
\text { practice issues as: efficiency } \\
\text { measures taken, use of } \\
\text { alternative energy sources. }\end{array}$ & $\begin{array}{l}\text { Score based on: risk factors for } \\
\text { rainfall and wind erosion. Land } \\
\text { management practices are } \\
\text { assessed relative to site } \\
\text { susceptibility to erosion. }\end{array}$ & $\begin{array}{l}\text { Score for nitrate leaching based } \\
\text { on the difference between } \\
\text { actual and advised } \mathrm{N} \\
\text { application rates, application } \\
\text { timing and soil type are } \\
\text { considered. }\end{array}$ & $\begin{array}{l}\text { Score based on: general } \\
\text { management, management of } \\
\text { hedges, field margins, ditches, } \\
\text { water bodies and woodland. }\end{array}$ \\
\hline 4 DIA & $\begin{array}{l}\text { Input of direct energies } \\
(\mathrm{GJ} / \mathrm{ha}) \text {. }\end{array}$ & $\begin{array}{l}\text { Fraction of farmed surface } \\
\text { without crop cover on } \\
\text { December } 31 \text { (ha/ha). }\end{array}$ & $\begin{array}{l}\text { Farm level } \mathrm{N} \text {-surplus, sum of } \\
\text { all imported } \mathrm{N} \text { minus all } \mathrm{N} \text { in } \\
\text { sold products, corrected for } \\
\text { changes in stocks }(\mathrm{kg} / \mathrm{ha}) \text {. }\end{array}$ & $\begin{array}{l}\text { Length of hedges and forest } \\
\text { borders }(\mathrm{m} / \mathrm{ha}) \text {. }\end{array}$ \\
\hline $5 \mathrm{LCAE}$ & $\begin{array}{l}\text { Input of direct and indirect } \\
\text { non-renewable energies }(G J / h a \\
\text { and } G J / k g) \text {. }\end{array}$ & $\begin{array}{l}\text { Amount of eroded soil } \\
\text { calculated using the Universal } \\
\text { Soil Loss Equation (USLE) } \\
\text { (kg/ha). }\end{array}$ & $\begin{array}{l}\text { Emissions of } \mathrm{NO}_{3}, \mathrm{NH}_{3} \text { and } \\
\mathrm{N}_{2} \mathrm{O} \text { calculated by emission } \\
\text { factors and simulation models } \\
\text { ( } \mathrm{kg} / \mathrm{ha} \text { and } \mathrm{kg} / \mathrm{kg} \text { ). }\end{array}$ & \\
\hline $6 \mathrm{EF}$ & $\begin{array}{l}\text { Area of land required to } \\
\text { produce a crop-based substitute } \\
\text { for energy used or area of land } \\
\text { required to absorb } \mathrm{CO}_{2} \text { emitted } \\
\text { from fossil fuel. }\end{array}$ & & & \\
\hline
\end{tabular}

\footnotetext{
a See Table 1.

${ }^{\mathrm{b}}$ Direct energies: those directly used in the production activity (e.g. diesel used by tractor); indirect energies: those used to provide the other factors (e.g. fertiliser, diesel, the tractor).
} 
safe standards, the so-called levy free surpluses (LFS). If the individual farm surplus exceeds the LFS, the farmer will be taxed for every kilogram of nutrient exceeding the LFS (Ondersteijn et al., 2002). Although MINAS is obligatory and the Danish nutrient balance is voluntary, the basic principles of both approaches are equivalent.

\subsection{Ecopoints (EP)}

Mayrhofer et al. (1996) propose a method, which assigns scores to farm production practices and landscape maintenance. The method is used in lower Austria to establish the level of payments to farmers in order to favour desired management practices with respect to the environment and the landscape. In 1998, 1500 farms participated in the programme. The method assigns scores to farm practices (e.g. "D-indicators" such as crop rotation, maintenance of soil cover, intensity of use of fertilisers, pesticides, grassland management) and for the presence of landscape elements such as hedges, trees, wetlands, and orchards ( $\mathrm{S}$ indicators). For example, the farm gets zero points if it grows three or fewer different crops, one point for four crops, two points for five crops, etc. A catch crop yields five points; mulch covering the soil yields up to 6 points and direct drilling yields 3 points. The less fertiliser and pesticides used, the more points are obtained, and landscape elements yield points according to their area.

\subsection{Environmental management for agriculture (EMA)}

Lewis and Bardon (1998) propose "a computerbased informal environmental management system for agriculture". The system produces "eco-ratings", reflecting environmental performance by comparing actual farm production practices and site-specific details with what is perceived to be best practice for that site. Each indicator is thus a score between -100 and +100 based on the aggregation of a number of sub-indicators. For instance, for nitrogen fertiliser application the main impact is nitrate leaching. The tool provides a baseline eco-rating based on a calculation of the difference between the actual application rates and the recommended rates. This baseline factor is then enhanced by scores associated with site-spe- cific factors such as application timing, rainfall levels and soil type to establish a measure of environmental impact ( $\mathrm{P}$ indicator). The EMA tool incorporates modules to explore "What-If" scenarios and a hypertext information system. More than 5000 farmers and their advisors in the United Kingdom use the EMA tool.

\subsection{DIALECTE (DIA)}

Solagro (2000) proposes DIALECTE for the evaluation of the environment at the farm level by means of a comprehensive, simple and rapid approach. This method is an improved version of the "Solagro Diagnostic" method proposed by Pointereau et al. (1999). The method yields 16 Agro-Environmental Indicators supplying a rapid and global evaluation of the environmental risks of the farm. The indicators concern crop diversity, grassland management, manure and soil management, presence of hedges, input use, $\mathrm{N}$, $\mathrm{P}$ and $\mathrm{K}$ surplus as shown in Table 4 (thus a mix of $\mathrm{D}$, $\mathrm{P}$ and $\mathrm{S}$ indicators). It further produces a Whole Farm Approach consisting of an energy analysis, of performance levels for farm diversity and management of inputs, and of an assessment of the potential impacts of the farm on water, soil, biodiversity and resource use. These impacts are calculated as sums of scores based on several of the 16 agro-environmental indicators. The method can be applied to all agricultural production systems in France according to the author. So far the evaluation has been carried out for 1000 farms.

A number of similar approaches combining quantified indicators with subjective assessments of farm practices exist. Vilain (2003) proposes a method, which assigns scores to farm production and management practices. The method can be used for the evaluation of agroecological, socio-territorial and economic sustainability of different farm types in France.

\subsection{LCA for environmental farm management (LCAE)}

Several authors have adapted a general Life Cycle Assessment methodology to obtain a comprehensive evaluation of the environmental impact of a farm (Rossier, 1999; Cederberg and Mattsson, 2000; Haas 
et al., 2000; De Boer, 2003; Dalgaard et al., 2004). The method allows the identification of the main pollution sources through the chain (including production of farm inputs) as far as the farm gate and the evaluation of possible modifications of the farms or farming methods. Rossier (1999) applied the LCA approach to 13 crop, animal and mixed farms in Switzerland and in Denmark the system of Green Accounts has been supplemented with a tool for performing LCA on the farms, which has been tested on 20 private farms. These tools are, however, not widely used by farmers or advisors so far. In the Netherlands, for example, an energy yardstick has been developed, which applies an LCA based assessment of energy use. This yardstick has been tested on livestock production systems only, and is not used widely on commercial farms yet (Hanegraaf et al., 1996).

\subsection{Ecological footprint analysis (EFA)}

A farm's Ecological Footprint (EF) is the biologically productive area (BPA) needed to produce resources used and to absorb waste (i.e., $\mathrm{CO}_{2}$ from fossil fuel combustion) generated by that farm (Wackernagel and Rees, 1996). To compute the EF you keep track of land and energy requirements of all resources imported into the farm or used on the farm. Subsequently, total land and energy use are summed into BPA, assuming that 1 ha of woodland absorbs all $\mathrm{CO}_{2}$ released during combustion of $100 \mathrm{GJ}$ of energy. To be able to compare the ecological footprint of farms that differ in size, total BPA is divided by the total output using economic allocation between products and expressed per unit of product. Ecological footprint analysis, therefore, yields one environmental indicator, i.e., BPA (in $\mathrm{m}^{2}$ ) per kilogram of product.

The environmental assessment tools presented above vary both in the number and selection of environmental issues and in the type of indicators used. We distinguish between six types of indicators as shown in the following:

I. Indicators, which are merely a recording of the individual farmer's management practice (e.g. tools no. 2 and 3). This type of indicator is linked to concepts for Good Agricultural Prac- tice (GAP), which are rule-based guidelines for planning. Such GAP indicators may give a fast indication of the level of environmental awareness on the farm and indicate a Driving Force. However, such indicators are not very suitable for identifying important environmental impacts for a particular farm and for considering the potential improvements on that farm.

II. Indicators of resource use (input use) such as the energy or fertiliser use per hectare are quantified Driving Forces which may indicate the use of limited resources and the potential pressure on the environment. They have the advantage over type $I$ of allowing comparison between farms. But the relation to the environmental impact in question is indirect, because the level of emission from a certain input use depends on the amount of production achieved from this input.

III. Input-output indicators such as nutrient surplus have incorporated the efficiency of input use and are therefore better proxies for environmental impact than resource use or management indicators. However, the relation between the indicator (e.g. surplus of P per hectare) and the actual loss in a given period of time is not simple or linear, which again makes the interpretation difficult. The advantages of inputoutput indicators are that they are usually easy to calculate and explain to farmers, they are relatively precise and easy to standardise and very useful for benchmarking, because they may, to a large extent, be understood using classical production efficiency measures (e.g. feed efficiency).

IV. Estimates of emissions such as nitrate loss per hectare or ammonia loss per farm are Pressure indicators, which have the advantage of being closely related to the environmental problems in focus. However, they are usually not easy to estimate with precision without the availability of detailed data on the individual farm and they may depend on the use of complex models. Moreover, large differences exist in methods for emission modelling both within and between countries, which makes it difficult to compare studies.

V. The Life Cycle indicators in tool no. 5 also use emission estimates but aggregate several emis- 
sions into impact categories. Moreover, the impacts are often aggregated over several processes in the production chain and expressed per kilogram of product. The difference between this indicator type and the area-based inputoutput and emission indicators are discussed below.

VI. A few examples of (Environmental) State indicators are used such as the percentage of small biotopes (hedges, ponds, etc.) or the presence of landscape elements in tools nos. 2-4. Some of the indicator tools above do not speak of "evaluation of environmental impact" but use the expression "evaluation of ecological (or environmental) sustainability". Although this expression is not always clearly defined, it obviously envisages a situation in which environmental impact is limited to an acceptable level. As environmental sustainability is not a measurable entity in itself, most assessment tools use environmental indicators to evaluate environmental impact of contrasting production systems and to identify possible reasons for variation within and between production systems (Mitchell et al., 1995; Bell and Morse, 1999; OECD, 2000).

Most of the environmental assessment tools are meant for voluntary use, but only few attempts have been made to verify that these tools are actually used to improve the environmental performance (Halberg et al., 2005). The most promising tools seem to be the ones that are linked with production-oriented planning tools used in collaboration with local advisors. This is because the indicators on a given farm need to be interpreted in relation to both the objectives behind the indicator and the potential for improvement of the environmental performance on the particular farm. This process of benchmarking is discussed in the following section.

\section{Using indicators for improving livestock farming systems: from diagnosis to development}

The indicator tools described above may all be used to characterise different farming systems in relation to the objectives chosen, which may lead to a diagnosis of problematic issues. However, it is not evident how this may lead to improvements in the farming systems involved, i.e. going from diagnosis to development. The first step in this process will often be to identify reference values to compare the indicator value achieved on a specific farm with (e.g. public limits for emissions, estimated results when the farm follows norms for GAP, the variation among similar farms...). One method for this purpose is called benchmarking, which is the process of learning from farms with better agri-environmental performance in one or more indicators according to the following definition: "Benchmarking is the process of improving performance by continuously identifying, understanding and adapting outstanding practices and processes found inside and outside the organisation" (Amer. Prod and Quality Center, 1999, cit. EEA, 2001).

Thus, benchmarking is more than just comparing numbers from different companies (farms); it involves the process of identifying "best practices", understanding differences between farms, learning from an analysis of the reasons for this difference, setting goals for oneself based on the results achieved by others, and hence improving own practices. Therefore, for indicator tools to be useful for the development of environmentally improved farming systems, there should be a strong and known relation between the farming practice (i.e. the farm management) and the level of the indicator on a specific farm. Moreover, it should be possible to link the variation between farms/farming systems in their indicator values to differences in farm management or system properties. This is indeed the case for some important inputoutput based indicators, which has been shown in studies of farm data (Halberg et al., 1995; Halberg, 1999; Haas et al., 2000; Schröder et al., 2003; De Boer et al., 2004).

As an example of the benchmarking approach, the variation in farm gate P-surplus per hectare among Danish Pilot farms is shown in Fig. 1 (Nielsen, unpublished; Nielsen and Kristensen, 2005). The P-surplus increased-not surprisingly-with increased stocking density defined by livestock production per hectare. However, there is a difference between pig farms with identical stocking density (seen as the vertical variation at points on the $X$-axis, e.g. 1 Livestock Unit (LU) per ha. The two pig farms marked A and $\mathrm{B}$ both use manure from around $1 \mathrm{LU}$ per ha of 


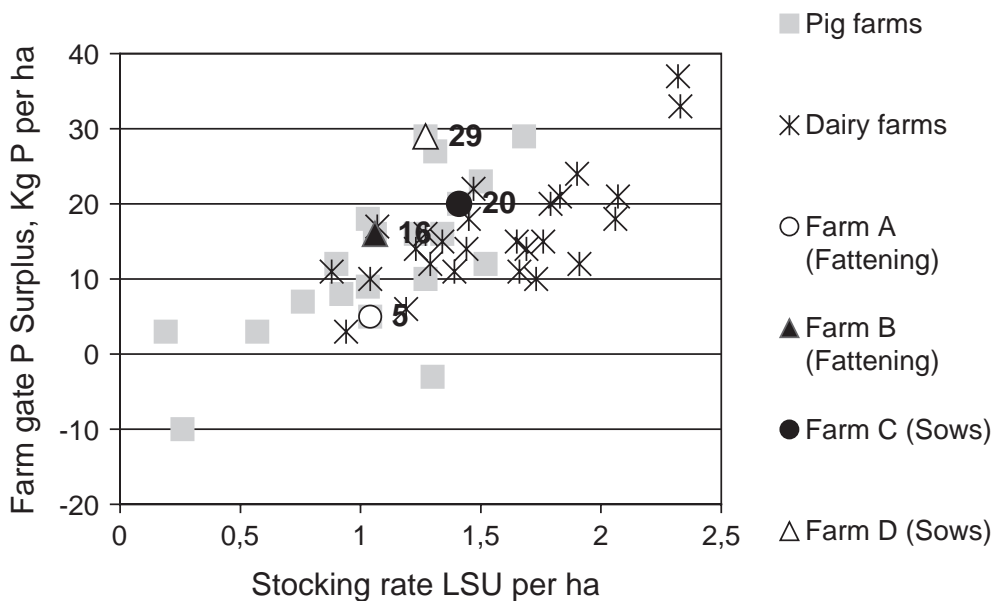

Fig. 1. Farm gate P-surplus in kilogram P per hectare by farm type and stocking density after net manure sale. Data from Danish pilot farms (1998-2003), observations are averages over 2-5 years per farm. Nielsen, unpublished.

fattening pigs (after correction for manure export) and should, therefore, have approximately the same farm gate P-surplus per hectare if they follow the same norms for feeding and fertilisation. Obviously, this is not the case; farm $\mathrm{B}$ has a higher $\mathrm{P}$ surplus per hectare than A (16 vs. $5 \mathrm{~kg}$ P per ha per year respectively). The reason for this difference can be explored by comparing the use of $\mathrm{P}$ on the two farms. Since the farms use almost the same amount of pig manure per hectare and purchase very little P fertiliser (results not shown), the reason for different farm level P-surpluses should be found in the P-efficiency in the crops and/or in the feeding practices. When calculating the herdlevel $P$ balances of the yearly pig production, it becomes clear that farm $\mathrm{B}$ supplies more $\mathrm{P}$ in manure to the crops than farm A does. As shown in Fig. 2, Farm B supplies $20 \mathrm{~kg} P$ per ha compared with $30 \mathrm{~kg}$ $\mathrm{P}$ from farm A, even though they had identical stocking density (Fig. 1). Thus, there should be a potential for farm B to reduce the farm level P surplus simply by optimising the supply of $\mathrm{P}$ in feed and minerals. The same picture emerges when comparing the piglet production of Sow farms C and D.

To move from the stage of understanding why some farms perform better than others as measured by a specific indicator to the task of actually improving the agri-environmental performance on a farm (either voluntarily or by regulation), it is necessary to link the diagnostic assessment tools to on-farm management strategies (Børsting et al., 2003; Schrö-

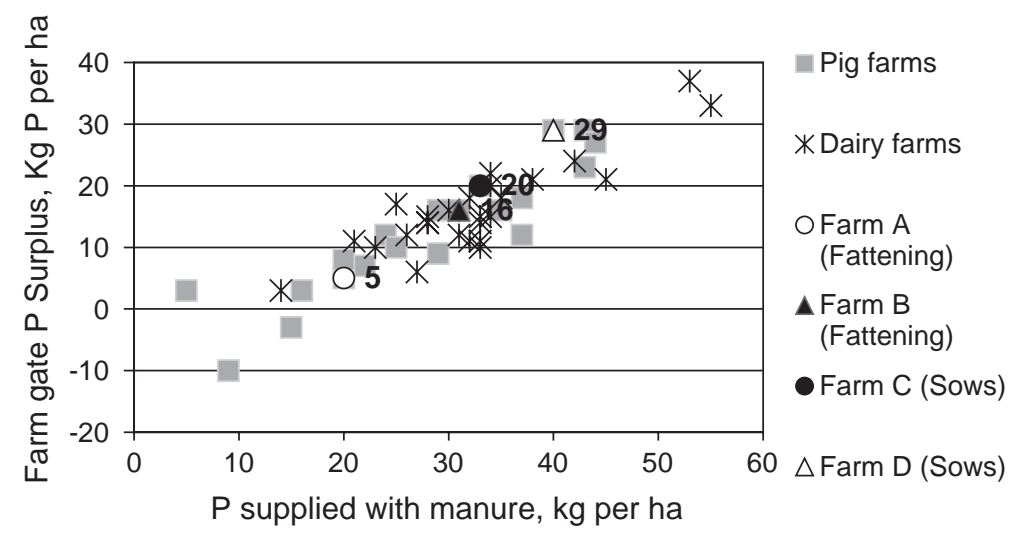

Fig. 2. Farm gate P-surplus in kilogram P per hectare by farm type and amount of P supplied with manure. Data from Danish pilot farms (19982003), observations are averages over $2-5$ years per farm. Nielsen, unpublished. 
der et al., 2003; Halberg et al., 2005). Model-based research has already indicated that, for example, the surplus of $\mathrm{N}$ and $\mathrm{P}$ per hectare could be mitigated by tactical and operational management (Van der Meer and Van der Putten, 1995; Halberg and Jensen, 1996; Børsting et al., 2003; Schröder et al., 2003). In addition, a demonstration project in the Netherlands, referred to as 'Cows and Opportunities', showed that use of nutrient accounting in combination with farm specific management advice, i.e., a detailed fertilisation scheme, significantly reduced individual farm surpluses (Hanegraaf and den Boer, 2003). Likewise, the use of the Dutch farm energy use analysis tool "the Energy Yardstick" has shown that it is possible to include the objective of energy savings in farm planning (Hanegraaf et al., 1996).

There seems, thus, to be evidence that benchmarking is a feasible process for the improvement of agrienvironmental performance when using different types of I/O indicators. More systematic data comparing different types of farming systems using such clearly defined and possibly standardised I/O accounting methods are needed for this to be useful on a large scale.

The situation is different for environmental indicators obtained from LCA, such as for example global warming or acidification potential per kilogram milk. So far, LCA studies at farm level use case studies (few farms) and reference values (i.e. the estimation of, e.g. $\mathrm{N}_{2} \mathrm{O}$ and $\mathrm{CH}_{4}$ is still based on relatively crude standard emission factors), and therefore show limited variation between farms. To gain insight into the between-farm variation of, for example, acidification potential per kilogram milk, variation in $\mathrm{NH}_{3}$ emission between farms is highly relevant. Prediction or measurement of variation in emission of gasses such as $\mathrm{NH}_{3}, \mathrm{~N}_{2} \mathrm{O}$ or $\mathrm{CH}_{4}$, however, appears to be difficult. Therefore, it is presently not easy to document differences in such emissions between otherwise comparable farms due to management at tactical or operational levels (i.e. things that might be changed in medium to short-term planning). The relation between manure handling and methane emissions is poorly understood and does not allow a farm specific calculation (Hansen et al., 2002). The relations between feeding and methane emission established in the literature are difficult to apply in practice, because of the level of detail needed regarding the chemical composition of carbohydrates (Bertilsson, 2002). However, the relation between methane loss from ruminants' digestion and the feeding practice may in the future be operationalised in a way that allows this to be taken into account when planning feeding management on a particular farm (Bertilsson, 2002).

The other significant contributor to greenhouse gas emission, nitrous oxide, cannot presently be measured or assessed precisely in relation to individual management practices such as manure handling techniques and crop rotation, and there is even a large difference between countries in the way the IPCC methodology is applied (Petersen et al., 2002). Hence, efforts to improve the methods for assessment of $\mathrm{NH}_{3}, \mathrm{~N}_{2} \mathrm{O}$ and $\mathrm{CH}_{4}$ emissions on farm scale should be continued and should be linked to an understanding of the underlying processes in order to use LCA indicators at farm level (De Boer, 2003). It would be a very important gain if the increased knowledge of causes for these emissions on a process level could be operationalised into management tools in the future. The prospects for estimating nitrate and ammonia emissions on specific farms are better, but even within a relatively small and homogenous country such as Denmark there is still no consensus on which model to use to assess nitrate losses from specific farms.

\section{Comparison of the land-based indicators and assessment}

Both for the comparison of contrasting production systems and for the identification of options for improvement, the definition of the environmental indicator used is highly important as discussed above. Most indicator tools present the environmental impacts per hectare and most systems include only the emissions from the farm itself (Tables 2, 3; see also Goodlass et al., 2003). Thus in this sense they are "site-specific". However, some environmental impacts, e.g. greenhouse gas emission, are of a global nature and therefore the emission per unit produced (e.g. $1 \mathrm{~kg}$ milk) is as relevant from a global, environmental perspective as the emissions per hectare. Also indirect emissions related to the use of inputs on a farm (e.g. the environmental impact from producing the imported feeds and fertiliser, Van der Werf et al., 2005) should be included when a comprehensive assessment of the 
environmental consequences of a product is needed. The impact of, e.g. nitrous oxide emissions from soybean cultivation in tropical countries may be as relevant to the assessment of European livestock production as the greenhouse gas losses from the animals themselves. Moreover, increasingly it is recognised that environmental gains from improvement in farming systems per se may be off-set by the amounts and patterns of consumption, which is one of the reasons for the EU IPP policy paper (Anonymous, 2003). Therefore, the definition of system boundaries is very important for indicator selection and for interpretation of results.

For these reasons, a product-oriented assessment that includes the whole production chain and quantifies the environmental impacts per kilogram product delivered is recommended internationally (Anonymous, 2003; UNEP, 2004). Life Cycle Assessment is the most developed product-oriented assessment tool and is increasingly used to evaluate the environmental efficiency of different agri-enterprises and food production systems (Halberg, 2004). For a correct interpretation of obtained results of each indicator, however, it makes a difference whether the environmental impact assessed is expressed relative to the amount of product produced (product-based approach) or relative to the amount of farmland used (area-based approach) (De Boer, 2003). This will be illustrated below with examples from different European farming systems - dairy and pig production. In Table 5 we review results of LCA case studies that compare results of organic and conventional dairy production systems (Cederberg, 1998; Cederberg and Mattsson, 2000; Iepema and Pijnenburg, 2001; Haas et al., 2001; Dalgaard et al., 2004). At present, we cannot directly compare LCA results of different case studies (De Boer, 2003) because of methodological differences. LCA results of organic milk production, therefore, are expressed relative to conventional production.

The environmental impact per hectare is lower for organic dairy farms than for conventional farms in most cases, e.g. Global Warming Potential (GWP, the total amount of greenhouse gasses converted to $\mathrm{CO}_{2}-$ equivalents) per hectare of organic production is $42-$ $102 \%$ of GWP of conventional production (Table 5). However, in Germany, Sweden and Denmark the milk production per hectare is also smaller and therefore the results change when impacts are expressed per ton milk. Expressed per tonne of milk the GWP of organic production is $91-104 \%$ of the GWP of conventional production. Using the product-based approach, we would conclude that GWP of organic and conventional production are almost equivalent. Using the areabased approach, we would conclude that GWP is lower for organic than for conventional production, except for the Dutch situation. With respect to acidification and eutrophication a similar conclusion can be drawn. However, for results expressed per hectare, the Dutch organic system does not do better than the conventional system with respect to acidification.

A comparison of French pig production systems shows the same difference in ranking depending on product-based or area-based environmental assessment (Basset-Mens and van der Werf, 2005, Table 6). The Good Agricultural Practice (GAP) scenario

Table 5

Environmental impacts expressed per tonne milk produced or per hectare farm area for contrasting dairy production systems ${ }^{\mathrm{a}}$

\begin{tabular}{|c|c|c|c|c|c|c|c|}
\hline \multirow[t]{2}{*}{ Case study } & \multirow[t]{2}{*}{ Production system } & \multicolumn{2}{|c|}{ Global warming potential $(\%)^{\mathrm{b}}$} & \multicolumn{2}{|c|}{ Acidification potential $(\%)^{b}$} & \multicolumn{2}{|c|}{ Eutrophication potential $(\%)^{\mathrm{b}}$} \\
\hline & & t milk & ha & $\mathrm{t}$ milk & ha & $\mathrm{t}$ milk & ha \\
\hline \multirow[t]{2}{*}{ German } & Conventional & 100 & 100 & 100 & 100 & 100 & 100 \\
\hline & Organic & 100 & 67 & 116 & 79 & 37 & 26 \\
\hline \multirow{2}{*}{ Sweden } & Conventional & 100 & 100 & 100 & 100 & 100 & 100 \\
\hline & Organic & 95 & 42 & 89 & 40 & 113 & 50 \\
\hline \multirow[t]{2}{*}{ The Netherlands } & Conventional & 100 & 100 & 100 & 100 & 100 & 100 \\
\hline & Organic & 104 & 102 & 100 & 99 & 49 & 48 \\
\hline \multirow[t]{2}{*}{ Denmark } & Conventional & 100 & 100 & 100 & 100 & 100 & 100 \\
\hline & Organic & 91 & 68 & 90 & 62 & 56 & 40 \\
\hline
\end{tabular}

Relative numbers, Conventional system $=100$ for each country.

${ }^{\text {a }}$ Generated from De Boer, 2003; Dalgaard et al., 2004.

${ }^{\mathrm{b}}$ For each case study the organic system is expressed relative to the conventional system. 
Table 6

Comparison of three pig production systems (Good Agricultural Practice (GAP), Red Label (RL) and Organic Agriculture (OA)) expressed in impact categories per kilogram of pig produced and per hectare of land use ${ }^{a}$

\begin{tabular}{|c|c|c|c|c|c|c|}
\hline \multirow[t]{2}{*}{ Impact category } & \multicolumn{3}{|c|}{ Per kilogram of pig, $\%{ }^{b}$} & \multicolumn{3}{|c|}{ Per hectare, $\%{ }^{\mathrm{b}}$} \\
\hline & GAP & RL & $\mathrm{OA}$ & GAP & RL & $\mathrm{OA}$ \\
\hline Eutrophication $\left(\mathrm{kg} \mathrm{PO}_{4}\right.$-eq) & 100 & 80 & 104 & 100 & 69 & 57 \\
\hline Climate change ( $\mathrm{kg} \mathrm{CO}_{2}$-eq) & 100 & 150 & 173 & 100 & 130 & 95 \\
\hline Acidification ( $\mathrm{kg} \mathrm{SO}_{2}$-eq) & 100 & 52 & 86 & 100 & 45 & 47 \\
\hline Terrestrial toxicity (kg 1.4-DCB-eq) & 100 & 112 & 184 & 100 & 96 & 101 \\
\hline Non-renewable energy (MJ) [JHE1] & 100 & 113 & 140 & 100 & 97 & 77 \\
\hline Land use ( $\mathrm{m}^{2}$ per year) & 100 & 116 & 182 & 100 & 100 & 100 \\
\hline Pesticide use (kg active matter) & 100 & 105 & 17 & 100 & 92 & 10 \\
\hline Pig produced (kg) & 100 & 100 & 100 & 100 & 86 & 55 \\
\hline
\end{tabular}

Relative numbers, GAP $=100$.

${ }^{a}$ Generated from Basset-Mens and van der Werf, 2005.

${ }^{b}$ For each unit of scale the organic and RL systems are expressed relative to the GAP system.

corresponds to conventional intensive production with good agricultural practice. The Organic Agriculture (OA) scenario corresponds to organic agriculture. The Red Label (RL) scenario corresponds to a French quality label (animal welfare, meat quality).

The choice between product-based and area-based assessment and evaluations of production systems is a political or normative one that has implications for which environmental issues will be most important, local or global, and which function of the production system should be highlighted. This choice is crucial when comparing systems with very different degrees of productivity (yields per unit land) because the extensive farming systems usually have lower yields and emissions per hectare, but above average emissions per kilogram product compared with more intensive systems (defined in terms of input use per hectare or livestock unit). Taking the pig production systems GAP versus RL as an example, the analysis of the results, both per hectare and per kilogram of pig, suggested that RL might be an interesting alternative to GAP (lower eutrophication and lower acidification impacts, Table 6), provided that the emissions responsible for climate change could be better controlled with RL. The comparison between GAP and OA, however, strongly depended on the way results are expressed. Impacts for OA were generally similar to or lower than those for GAP when compared per hectare of land used. But the GAP scenario presented better or similar results on a product basis (per kilogram of pig produced), except for pesticide use.
An area-based - compared with a product-basedagri-environmental indicator reflects intensity or extensiveness of production (defined here by inputs per hectare). In general, organic systems are more extensive than conventional systems (except for the Dutch case), and show a lower environmental impact per farm area. The low emissions from extensive systems may have local or regional benefits. But if the lower production is compensated for by more intensive production in other areas (regions), then the total emission on a global scale may be the same or even higher. Therefore, from a global perspective the interesting indicator is the emission per kilogram product.

This is in agreement with the proposition of Haas et al. (2000) and De Boer (2003) that the choice of the indicator should be connected with the impact category type: an area-based indicator should be preferred for regional impacts (such as eutrophication and acidification) and product-based indicators should be used for global impacts (e.g. climate change) (Table 6). In the pig farming example, the OA would then be better for the regional impacts (except terrestrial toxicity) and GAP would be better for global impacts. With respect to GWP and acidification, the results in Table 5 show no clear difference between conventional and organic milk production per kilogram milk. However, eutrophication per tonne milk is lower in (most) organic systems. Thus, for a global environmental problem, a production system that produces $1 \mathrm{~kg}$ of milk or meat with minimal environmental impact seems most efficient. This is of increasing importance because of the increasing demand worldwide for live- 
stock products (Delgado et al., 1999). For an environmental problem with a local or regional character, however, we could argue that looking at an areabased indicator is informative as well, especially because there are regional differences in the tolerance of emissions such as acidification. Knowing that farms are not evenly distributed over a region/country/ world, an area-related indicator gives information about the environmental load per farm area. Hence, for acidification and eutrophication, i.e., environmental problems with a regional component, we should compare contrasting production system using both a product and an area-based indicator.

However, changing the indicator basis also often changes systems boundaries, i.e. the definition of which impacts and resource flows to include. Thus, when calculating eutrophication and acidification per hectare (area-based), the result most often only includes the emissions on the particular farm and not the emissions during production of imported fertiliser or soybeans. These emissions are, on the contrary, included in the product-based assessment because this includes all steps from cradle to consumer. Moreover, emissions resulting from handling of manure exported from specialised livestock farms to cash crop farms are usually not included in the areabased assessment of the livestock farm (Schröder et al., 2003), but should be included in the product-based assessment. Therefore, each assessment has its advantage but cannot stand alone. An area-based assessment of livestock farming systems that depend on imported feeds and export large amounts of manure would overlook the emissions outside the farm related to the livestock production. On the other hand, a product-based assessment cannot presently distinguish between the different impacts a given level of emissions has on different locations. Thus, both types of indicators are needed in order to comprehensively characterise environmental impacts from food production.

\section{Selection of agri-environmental issues for the indicator tools}

As shown in Tables 3 and 4, most agri-environmental assessment tools cover only part of the extensive list of agri-environmental topics and problems, yet the normative (value-based) objectives behind the selection are rarely explicitly included in the systems' documentation. Most indicators are obviously uncontroversial, because they represent a sympathetic objective (e.g. reducing eutrophication or pesticide losses and maintaining biodiversity) as shown in Table 3. But the selection of some indicators over others is already a normative (i.e. value-based) choice and signals that some problems are considered more important than others. Not all indicator tools in Table 3 include, for example, pesticide use or emissions, which by the EU and many member states are considered important causes of environmental impact from farming (EEA, 2003). Some systems (DIA and EF) do not cover the use or potential loss of phosphorus, but focus on, for example, soil erosion and land use. Soil erosion/soil quality (which is another important topic according to EEA, 2003), on the other hand, is addressed only by four of the methods, partly because of a lack of simple indicators at the farm or field level (Halberg et al., 2005; Schjønning et al., 2004). All systems except EP include energy use, but it is not always clear whether this is from the perspective of a limited resource or the contribution of $\mathrm{CO}_{2}$ to global warming.

Moreover, the issue of balancing the different objectives, e.g., the trade-off between different indicators if they cannot all be improved at the same time, is seldom dealt with in an explicit way. Some systems transfer the indicator values to closed scales signalling maximum acceptable levels and comparisons between different issues, which often are based on researchers own perceptions or subjective views (Halberg et al., 2005). Other systems simply report the level of an indicator and in some cases offer reference values for comparison.

The objectives behind indicators for water use and fertiliser use are to promote "optimal" use, thus not necessarily to minimise the input. On a livestock farm the water consumption by livestock or the irrigation should cover the needs of animals and crops, but at the same time avoid waste. Thus, there is a need for interpretation of what is a reasonable level on a given farm. For other indicators the objective is to minimise, e.g. the surplus of nitrogen $(\mathrm{N})$ or the $\mathrm{N}$ emission, which seems simple, and most often the indicator is based on the area used $\left(\mathrm{NH}_{3}\right.$ emission per hectare). However, in a situation with conflicting objectives between production and emissions, it may be interest- 
ing to base the indicator on the amount of product (e.g. $\mathrm{NH}_{3}$ emission per kilogram wheat), in order to facilitate an explicit trade-off. The life cycle assessment methodology allows for a calculation of emissions per kilogram product and includes explicit functions for scaling different environmental impacts in the so-called "normalisation procedure" (Guinée et al., 2002).

In the end, any choice of which impacts from livestock systems are more important to address in a given context will be political decisions, depending on a local or regional/national context and the discourses in society (Kristensen and Halberg, 1997). Researchers need to justify explicitly their choices of objectives and indicators in relation to societal goals such as reflected in the environmental assessments from the European Environmental Agency (EEA, 2003, in press). Some objectives and the related indicators address environmental issues at the local or regional level (e.g., land use, biodiversity and soil erosion) while others focus on global issues (e.g., energy use and the release of greenhouse gasses). This may have consequences for the assessment of different livestock production systems and thus the choice of interventions. It thus seems obvious that there is a need for consensus concerning a list of basic agri-environmental indicators to assess different livestock farming systems in relation to clear objectives. Table 7 shows recommendations for agri-environmental indicators for use at the local, regional and global scale for diagnostic and development purposes. The table is not exclusive and mainly proposes a structure for selecting indicators based on considerations of the geographical scale and system boundary they should be interpreted within. The objectives and environmental themes correspond to objectives behind the IRENA indicators (EEA, in press) but do not include all (e.g. water abstraction). The indicators presented are suitable for use on specific farms or for specific products and processes. Therefore they differ from the IRENA indicators, which are selected to be useful on an aggregated level, using statistical data. The methodology for each indicator in Table 7 has been described elsewhere but more work is needed in order to harmonise specific calculation and interpretation procedures.

For each environmental objective there is a need for both diagnostic indicators and assessment tools for development (optimisation) purposes. Diagnostic indicators need to be relatively simple to carry out and to report, but should still give a precise assessment of the relation between production practices and the (potential) environmental impact. Indicators such as $\mathrm{N}$ and $\mathrm{P}$ surplus per hectare, pesticide "Treatment Frequency Index" or "kg active ingredients per ha" and energy use in "MJ per $\mathrm{kg}$ product" are well established in a number of countries. The LCA type indicators for GWP, eutrophication and acidification per kilogram product are well-established, but methodological differences are still too large to allow detailed comparisons between results from different researchers. Land use is part of LCA tools and was interpreted to reflect three competing objectives of: I. Biodiversity protection through sustaining and increasing uncultivated areas, e.g. rainforests and bogs. II. The need for land to secure global food sufficiency (Runge et al., 2003). III. Bio energy production (EEA, 2003). The objective of minimising land use per produced unit does not always go hand in hand with the objective of maintaining semi-natural grasslands by grazing, which is a goal in many European countries (EEA, 2004a).

Some of the objectives, especially for landscape and biodiversity, cannot be described satisfactorily by single and general indicators because of geographical and cultural differences. The Austrian concept "Ecopoints" operates with a list including "the percentage of small biotopes on the farm", which may have a general validity but which does not tell much about the actual biodiversity in, e.g. the hedges or ponds. Some attempts to define generic landscape (aesthetical) indicators exist, but the subjective and normative aspects of landscape aesthetics should be considered carefully as part of the process for such indicators (Højring and Noe, 2004). No consensus exists on appropriate and simple soil quality indicators to be used on individual farms or fields (Schjønning et al., 2004), but some feasible indicators of specific aspects of soil quality can be selected such as the amount of toxic substances applied (e.g. "kg Cu per ha").

In conclusion: For an indicator to be useful it is necessary to establish reference values for different types of livestock farming systems. This should be done by analysing data from farms to demonstrate the variation in indicator values and by testing the possibilities of reducing environmental impacts 
Table 7

Recommended indicators ${ }^{1}$ for agri-environmental assessment tools of livestock farming systems by objective and geographical scale

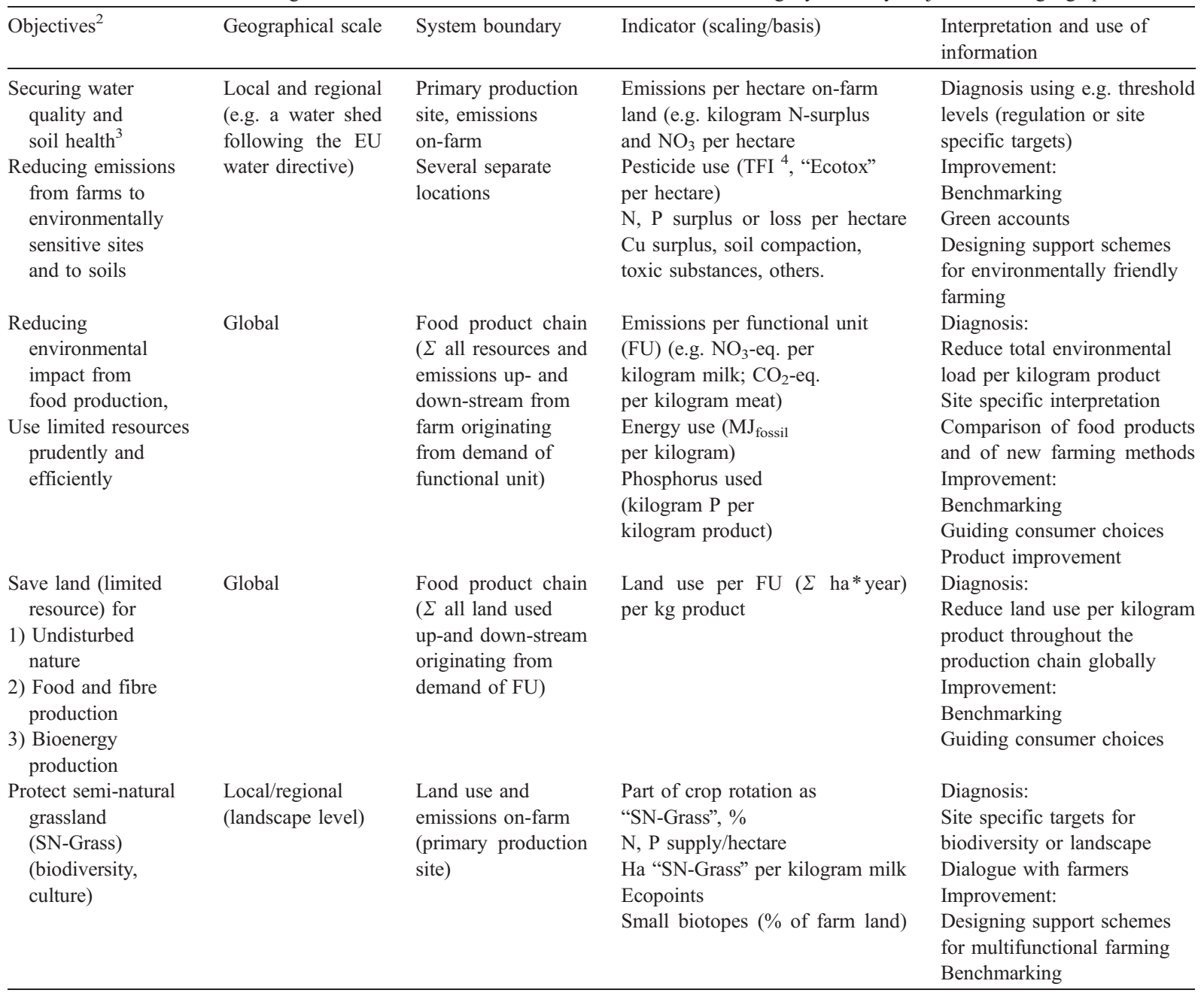

1) The indicators were chosen among the indicators used in the reviewed assessment tools following criteria explained in Halberg et al., 2005. Quantitative indicators that document changes over time and differences between farms and are realistic to calculate and explain to non-experts were preferred. The list is not to be considered inclusive.

2) The table proposes a structure for indicator selection based on explicit choices of the geographical scale, the system boundaries and possibilities for interpretation given a priori objectives. The objectives reflect the reviewed tools and were checked against internationally stated, environmental goals as expressed by the EU (EAA, 2003, 2004b, in press) and UNEP (2004). The list of objectives should not be considered exclusive, and some objectives, such as sustainable water use (EEA, in press) were not included here.

3) No consensus exists on appropriate and simple Soil quality indicators to be used on individual farms, but some feasible indicators of specific aspects of soil quality can be mentioned.

4) Treatment Frequency Index (see GE) is operational but does not distinguish between pesticides with different toxicity. Other indicators should be developed.

using farm-scale modelling. Moreover, for such efforts to be taken up by farmers it is necessary to introduce methods for benchmarking and development as part of advisory services. Benchmarking processes should include several steps, most importantly the establishment of valid reference values for a farmer to compare his results with, interpretation and understanding of causes for differences 
between farms, explorations of possible ways to improve the environmental performance on specific farms through changed tactical and strategic planning, and holistic evaluation of the consequences of such partial improvements for the overall economic, environmental and animal welfare performance of the farming system using indicators. For each of these steps more readily available tools should be developed for farmers and advisors to be linked with traditional technical-economic planning tools.

\section{References}

Anonymous, 2000. Vejledning om grønne regnskaber for landbrugsbedrifter (Manual for Green Accounts for a Farms). Landbrugets Rådgivningscenter. 90 pp. Available on-line: http://www.lr.dk// groentregnskab (feb. 2003).

Anonymous, 2003. Integrated Product Policy. Building on Environmental Life-Cycle Thinking. Communication from the Commission to the Council and the European Parliament Commission of the European Communities. Brussels, 18.6.2003, COM(2003) 302 final.

Basset-Mens, C., van der Werf, H.M.G., 2005. Scenario-based environmental assessment of farming systems: the case of pig production in France. Agriculture, Ecosystems and Environment 105, 127-144.

Bell, S., Morse, S., 1999. Sustainability Indicators, Measuring the Immeasurable. Earthscan Publications Ltd, London.

Bertilsson, J., 2002. Methane emissions from enteric fermentationeffects of diet composition. In: Petersen, S.O., Olesen, J. (Eds.), Greenhouse Gas Inventories for Agriculture in the Nordic Countries. Proceedings from an International Workshop, DIAS Report, vol. 81, pp. 37-45.

Børsting, C.F., Kristensen, T., Misciatteli, L., Hvelplund, T., Weisbjerg, M.R., 2003. Reducing nitrogen surplus from dairy farms. Effects of feeding and management. Livestock Production Science $83,165-178$.

Bureau Heffingen, 2001. MINAS Tabellenbrochure 2001. Ministerie van Landbouw, Natuurbeheer en Visserij, Assen, The Netherlands.

Cederberg, C., 1998. Life cycle assessment of milk production-a comparison of conventional and organic farming, SIK-report, no. 643, SIK, The Swedish Institute for Food and Biotechnology, Göteborg.

Cederberg, C., Mattsson, B., 2000. Life cycle assessment of milk production-a comparison of conventional and organic farming. Journal of Cleaner Production 8, 49-60.

Dalgaard, R., Halberg, N., Kristensen, I.S., Larsen, I., 2004. An LC inventory based on representative and coherent farm types. In: Halberg, N. (Ed.), Life Cycle Assessment in the Agri-food Sector. Proceedings from the 4th International Conference, October 6-8, 2003, Bygholm, Denmark DIAS Report, vol. 61, pp. 98-106. Available on-line (Oct. 2004):
http://www.lcafood.dk/lca_conf/DJFrapport_paper_2_poster. pdf.

De Boer, I.J.M., 2003. Environmental impact assessment of conventional and organic milk production. Livestock Production Science 80, 69-77.

De Boer, I.J.M., Iepema, G., Thomassen, M.A., 2004. Environmental impact assessment at commercial dairy farms. In: Halberg, N. (Ed.), Life Cycle Assessment in the Agri-food Sector. Proceedings from the 4th International Conference October 6-8, 2003, Bygholm, Denmark DIAS Report, vol. 61, pp. 214-218. Available on-line (Oct. 2004) at: http://www.lcafood.dk/lca conf/DJFrapport_paper_2_poster.pdf.

Delgado, C., Rosegrant, M., Steinfeld, H., Ehui, S., Courbois, C., 1999. Livestock to 2020: the next food revolution. Discussion Paper, vol. 28, 70 pp. IFPRI. Available on-line (August 2004): http://www.ifpri.org/2020/dp/dp28.pdf.

EEA, 2001. Environmental benchmarking for local authorities: from concept to practice. Environmental Issue Report, vol. 20. European Environmental Agency.

EEA, 2003. Europe's environment: the third assessment. Environmental assessment report, no. 10. Agriculture, 43-51;

EEA, 2003. Europe's environment: the third assessment. Environmental assessment report, no. 10. Soil Degradation, $198-212$.

EEA, 2004a. High nature value Farmland. EEA report no. 1/2004, $24 \mathrm{pp}$.

EEA, 2004b. IRENA, Indicator Reporting on the Integration of Environmental Concerns into Agricultural Policy (Available online (May 2004) http://webpubs.eea.eu.int/content/irena/index.htm.

EEA, in press. Agriculture and Environment in EU-15: the IRENA indicator report. (On-line: http://webpubs.eea.eu.int/content/ irena/Latestproducts.htm).

Goodlass, G., Halberg, H., Vershuur, G., 2003. Input output accounting systems in the European community - an appraisal of their usefulness in raising awareness of environmental problems. European Journal of Agronomy 20, 17-24.

Guinée, J.B., Gorrée, M., Heijungs, R., Huppes, G., Kleijn, R., de Koning, A., van Oers, L., Wegener Sleeswijk, A., Suh, S., Udo de Haes, H.A., de Bruijn, H., van Duin, R., Huijbregts, M.A.J., 2002. Life cycle assessment. An Operational Guide to the ISO Standards. Centre of Environmental Science, Leiden University, Leiden, The Netherlands.

Haas, G., Wetterich, F., Geier, U., 2000. Life cycle assessment framework in agriculture on the farm level. International Journal of Life Cycle Assessment 5, 345-348.

Haas, G., Wetterich, F., Köpke, U., 2001. Comparing intensive, extensified and organic grassland farming in southern Germany by process life cycle assessment. Agriculture, Ecosystems and Environment 83, 43-53.

Halberg, N., 1999. Indicators of resource use and environmental impact for use in a decision aid for Danish livestock farmers. Agriculture, Ecosystems and Environment 76, 17-30.

Halberg, N. (Ed.), 2004. Life cycle assessment in the agri-food sector. Proceedings from the 4th International Conference October 6-8, 2003, Bygholm, Denmark DIAS Report, vol. 61, 288 pp. Available on-line (Oct. 2004) at: http://www.lcafood.dk/ 1ca_conf. 
Halberg, N., Jensen, C.H., 1996. Dairy farm production strategy and nitrogen surplus. In: Walter-Jørgensen, Aa., Pilegaard, S. (Eds.), Integrated Environmental and Economic Analyses in Agriculture, SJFI-rapport, vol. 89, pp. 103-120.

Halberg, N., Kristensen, E.S., Kristensen, I.S., 1995. Nitrogen turnover on organic and conventional mixed farms. Journal of Agricultural and Environmental Ethics 8 (1), $30-51$.

Halberg, N., Verschuur, G., Goodlass, G., 2005. Farm level environmental indicators; are they useful? An overview of green accounting systems for European farms. Agriculture, Ecosystems and Environment 105, 195-212.

Hanegraaf, M.C., den Boer, D.J., 2003. Prespectives and limitations of the Dutch minerals accounting system (MINAS). European Journal of Agronomy 20, 25-31.

Hanegraaf, M.C., van Bergen, J.A.M., Biewinga, E.E., van Miltenburg, J., 1996. Ervaringen met de energiemeetlat in de veehouderij: cijfers, methodiek, rekenregels. Centrum voor Landbouw en Milieu, Utrecht.

Hansen, M.N., Sommer, S.G., Henriksen, K., 2002. Methane emission from livestock manure-effects of storage conditions and climate. In: Petersen, S.O., Olesen, J. (Eds.), Greenhouse Gas Inventories for Agriculture in the Nordic Countries. Proceedings from an International Workshop, DIAS Report, vol. 81, pp. $37-45$.

Holbeck, H.B., Kolind Hvid, S., 2004. Næringsstofoverskud på kvæg-, svine-og planteavlsbedrifter i demonstrationsprojekt med grønne regnskaber 1999-2001 (Nutrient surplus on dairy, pig and cash crop farms performing green accounts). Available on-line (September 3rd, 2004) at http://www.lr.dk/planteavl/ diverse/groent_regnskab.htm.

Højring, K., Noe, E., 2004. Communicative approaches to involve farmers in solving conflicts related to rural landscapes and nature. Paper for the XI World Congress of Rutal Sociology July, 2004, Trondheim, Norway.

Iepema, G., Pijnenburg, J. 2001. Conventional versus Organic Dairy Farming. A Comparison of Three Experimental Farms on Environmental Impact, Animal Health and Animal Welfare. MSc Thesis Animal Production Systems Group, Wageningen University, Wageningen, The Netherlands.

Kristensen, E.S., Halberg, N., 1997. A systems approach for assessing sustainability in livestock farms. Proceedings of the Fourth International Symposium on Livestock Farming Systems, EAAP Publication, vol. 89, pp. 16-29.

Lewis, K.A., Bardon, K.S., 1998. A computer-based informal environmental management system for agriculture. Environmental Modelling and Software 13, 123-137.

Mayrhofer, P., Steiner, C., Gärber, E., Gruber, E., 1996. Regionalprogramm Ökopunkte Niederösterreich. Informationsheft. NÖ Landschaftsfonds. Wien, Austria.

Mitchell, G., May, A., McDonald, A., 1995. PICABUE: a methodological framework for the development of indicators of sustainable development. International Journal of Sustainable Development and World Ecology 2, 104-123.

Nielsen, A.H., unpublished. Phosphorus balances based on data from Danish Pilot Farms. Danish Institute of Agricultural Sciences, Department of Agroecology.
Nielsen, A.H., Kristensen, I.S., 2005. Level of nitrogen and phosphorus surpluses on Danish dairy and pig farms in relation to farm characteristics. doi:10.1016/j.livprodsci.2005.05.012.

OECD, 2000. Towards sustainable development. Indicators to Measure Progress. OECD Publications, Paris.

Ondersteijn, C.J.M, Beldman, A.C.G., Daatselaar, C.H.G., Giesen, G.W.J., Huirne, R.B.M., 2002. The Dutch mineral accounting systems and the European nitrate directive: implications for $\mathrm{N}$ and $\mathrm{P}$ management and farm performance. Agriculture, Ecosystems and Environment 92, 283-296.

Petersen, S.O., Adolfsson, R., Fenhann, J., Halsdottir, B., Hoem, B., Regina, K., Rypdal, K., Staaf, H., Olesen, J., 2002. Comparison of national and IPCC default methodologies to estimate methane and nitrous oxide emissions from agriculture. In: Petersen, S.O., Olesen, J. (Eds.), Greenhouse Gas Inventories for Agriculture in the Nordic Countries. Proceedings from an International Workshop, DIAS Report, vol. 81, pp. 21-36.

Pointereau, P., Bochu, J.L., Doublet, S., Meiffren, I., Dimkic, C., Schumacher, W., Backhausen, J., Mayrhofer, P., 1999. Le diagnostic agri-environnemental pour une agriculture respectueuse de l'environnement. Trois méthodes passées à la loupe. Travaux et Innovations. Société Agricole et Rurale d'Edition et de Communication, Paris, France.

Rossier, D., 1999. L'écobilan, outil de gestion écologique de l'exploitation agricole? Revue suisse d'Agriculture 31 (4), $179-185$.

Runge, C.F., Senauer, B., Pardey, P.G., Rosegrant, M.W., 2003. Ending Hunger in our Lifetime-Food Security and Globalization. The Johns Hopkins University Press. $288 \mathrm{pp}$.

Schjønning, P., Elmholt, S., Christensen, B.T., 2004. Soil quality management—synthesis. In: Schjønning, P., Elmholt, S., Christensen, B.T. (Eds.), Managing Soil Quality: Challenges in Modern Agriculture. CAB International, pp. 315-333. Chapter 18.

Schröder, J., Aarts, K.F.M., Ten Berge, H.F.M., van Keulen, H., Neeteson, J.J., 2003. An evaluation of whole-farm nitrogen balances and related indices for efficient nitrogen use. European Journal of Agronomy 20, 33-44.

Smeets, E., Weterings, R., Bosch, P., Büchele, M., Gee, D., 1999. Environmental indicators: typology and overview. EEA Technical Report 25, 1-19.

Solagro, 2000. DIALECTE, Diagnostic Liant Environnement et Contrat Territorial d'Exploitation. User manual, first version (February 2000), Solagro, Toulouse, France.

Stolze, M., Piorr, A., Häring, A., Dabbert, S., 2000. The environmental impacts of organic farming in Europe. Organic Farming in Europe: Economics and Policy, vol. 6. University of Hohenheim, Stuttgart. $126 \mathrm{pp}$.

UNEP, 2004. UNEP-SETAC life cycle initiative. Life Cycle Initiative's Newsletter, vol. 4. Available on-line (January, 2005): http://www.uneptie.org/pc/sustain/ lcinitiative/.

Van der Meer, H.G., Van der Putten, A.H.J., 1995. Reduction of nutrient emissions from ruminant livestock farms. Proceedings of the British Grassland Society 50, 118-134.

Van der Werf, H.M.G., Petit, M., 2002. Evaluation of the environmental impact of agriculture at the farm level: a comparison and 
analysis of 12 indicator-based methods. Agriculture, Ecosystems and Environment 93, 131-145.

Van der Werf, H.M.G., Petit, J., Sanders, J., 2005. The environmental impact of the production of concentrated feed: the case of pig feed in Bretagne. Agricultural Systems 83, $153-177$.
Vilain, L., 2003. La méthode IDEA. Indicateurs de Durabilité des Exploitations Agricoles. Guide d'utilisation. Educagri éditions, Dijon, France.

Wackernagel, M., Rees, W.E., 1996. Our ecological footprint. Reducing the Human Impact on the EarthNew Society Publishers, Gabriola Island, British Columbia, Canada. 